\title{
DEVETDESET LET ODDELKA ZA GEOGRAFIJO FLLOZOFSKE FAKULTETE UNIVERZE V LJUBLJANI
}

Konec leta 2009 ni visokega 90-letnega jubileja praznovala samo Univerza v Ljubljani in njena članica Filozofska fakulteta, ampak tudi ljubljanski Oddelek za geografijo.

Slika 1: Sodelavci in sodelavke Oddelka za geografijo FF UL, junij 2009 (foto: M. Rebolj)

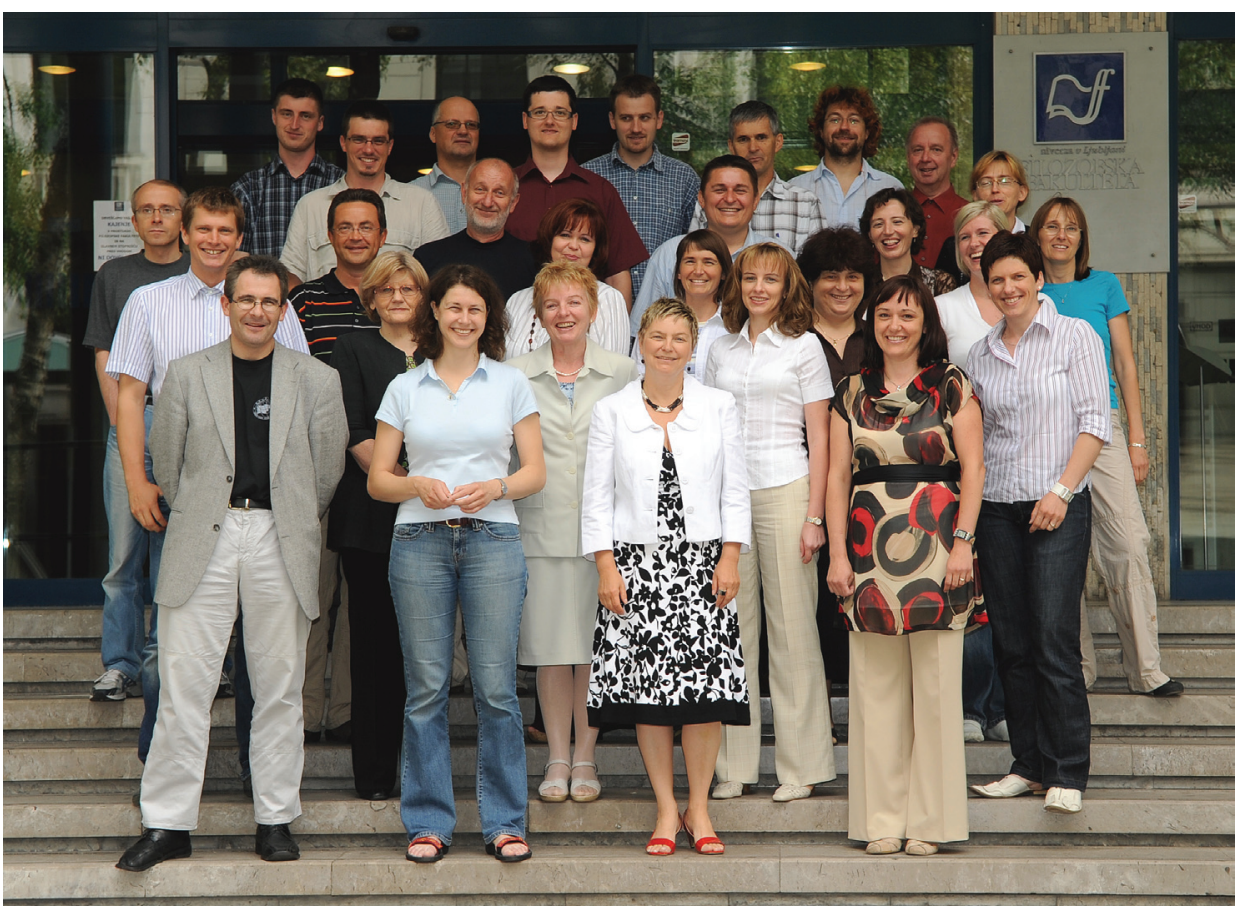

\section{KRATEK ZGODOVINSKI PREGLED RAZVOJA ODDELKA ZA GEOGRAFIJO FILOZOFSKE FAKULTETE UNIVERZE V LJUBLJANI}

Zgodovina današnjega Oddelka za geografijo Filozofske fakultete Univerze v Ljubljani (FF UL) se je začela pisati že leta 1919. Takrat sta bili na novoustanovljeni ljubljanski univerzi za geografijo predvideni kar dve stolici (fizična geografija, antropogeografija), vendar je bil šele aprila 1920 imenovan Artur Gavazzi za prvega rednega profesorja za geografijo, ki je z delom pričel leta 1921. Istega leta je bil v okviru Filozofske fakultete ustanovljen Geografski inštitut, v katerem je Gavazzi zbral okoli sebe skupino zagretih študentov in diplomantov (Valter Bohinec, Roman Savnik, Franjo Baš, Ivo Rubić in drugi), ki so leta 1922 ustanovili Geografsko društvo Slovenije. Kot dober organizator je že tedaj poskrbel za obsežno knjižnico in zbirko kart. Opremil je tudi laboratorij za limnološka in oceanografska 
raziskovanja. Delo Geografskega inštituta je povezal z vodenjem tedanjega Zavoda za meteorologijo in geodinamiko, ki so ga leta 1921 priključili k univerzi.

Študij geografije je v prvem obdobju potekal v glavnem po vzorcu avstrijskega študijskega sistema. Po odhodu Gavazzija na novo ustanovljeno katedro za fizično geografijo v Zagreb, je bil leta 1927 na njegovo mesto izvoljen Anton Melik, ki je nato s Svetozarjem Ilešičem od leta 1933 do konca šestdesetih let kreiral študij in znanstveno usmerjenost slovenske geografije. Z Melikom se je geografija na ljubljanski univerzi razvila ne le v duhu takrat moderne srednjeevropske geografske znanosti, temveč hkrati tudi kot nacionalna veda. Obenem se je tudi vsebinsko izpopolnila in tematsko zaokrožila. Melik in kasneje še Ilešič sta se z veliko vnemo lotila pedagoškega in znanstvenoraziskovalnega dela, neprestano pa se je tudi povečevalo število študentov. Osnovan je bil seminar ter uvedene intenzivne terenske vaje, ki so bile (z redkimi izjemami) organizirane tako za učno osebje kot za študente na lastne stroške. Ob Meliku in Ilešiču je slovenska geografska znanost suvereno in plodno vstopila v takratni jugoslovanski, evropski in svetovni znanstveni prostor. Leta 1925 je Geografsko društvo pričelo izdajati danes najstarejšo in osrednjo strokovno geografsko revijo Geografski vestnik, v znanstvenoraziskovalnem pogledu pa je bil poudarek na geomorfološkem, prebivalstvenem in agrarnogeografskem preučevanju historično-genetske oziroma fiziognomsko-morfološke smeri. Pod vplivom Melika je bil glavni poudarek na geomorfologiji, preučevanju naselij in agrarni geografiji.

Šele po 2. svetovni vojni je slovenska geografija kot ena najmlajših nacionalnih ved pridobila širše možnosti za organizacijski, študijski in vsebinski razmah, vendar sta se Melik in Ilešič vse do začetka 60-tih let sama ubadala z obsežnim pedagoškim delom, izdajo učbenikov, znanstvenoraziskovalnim delom in številnimi pomembnimi nestrokovnimi funkcijami. Potrebe so se zaradi naraščajočega števila študentov in uvajanja novih predmetov stopnjevale. Razmere so se izboljšale šele po letu 1959, ko je tretje predavateljsko mesto zasedel Vladimir Klemenčič, odobrenih in zasedenih pa je bilo tudi več asistentskih mest. V povojnem obdobju do leta 1960 je vsako leto diplomiralo vsaj 10 geografov, 12 geografov pa je doktoriralo.

Po ustanovitvi Geografskega inštituta Univerze (z zemljepisnim muzejem) je znanstvenoraziskovalno delo sodelavcev dobilo solidne organizacijske in finančne temelje, narejena pa je bila tudi smiselna razdelitev delovnih področij s takratnim Inštitutom za geografijo SAZU in Inštitutom za raziskovanje krasa v Postojni. Leta 1961 so Geografski inštitut pri Univerzi preimenovali v Oddelek za geografijo, ki je sčasoma pridobil tudi nove fakultetne učitelje in sodelavce (Igor Vrišer, Marjan Žagar, Darko Radinja, Vladimir Leban, Jakob Medved, Ivan Gams, Mirko Pak, Jurij Kunaver in drugi). Tako se je matična geografska enota močno okrepila. Takratni dvopredmetni in dvostopenjski študij je omogočal diplomantom zaposlitev na osnovnih in srednjih šolah, obenem pa se je začela krepiti zaposlitev izven šole. V letu 1966 se je začel tudi podiplomski študij, ki se je kasneje še razmahnil in postal pomembna oblika izpopolnjevanja najbolj nadarjenih diplomantov.

Po Ilešičevem mnenju si je ljubljanska geografska šola s svojim jedrom na Univerzi v 60-tih letih prejšnjega stoletja pridobila nadpovprečen ugled in neke vrste vodilno vlogo v takratni jugoslovanski geografiji, stopnjevala pa se je tudi živahna mednarodna dejavnost. Široko razvejana znanstvenoraziskovalna dejavnost članov oddelka je zaradi hitre preobrazbe 
slovenskih pokrajin in povečane specializacije raziskovanja segla na nova področja (geografija krasa, funkcijsko zasnovana klimatogeografija in hidrogeografija, biogeografija, preučevanje naravnih nesreč, preučevanje intenzivnih sprememb podeželja in mest zaradi deagrarizacije, urbanizacije, industrializacije in razvoja turizma, opredelitev in preučevanje narodnostno mešanih območij itd.). Leta 1957 je didaktika geografije pod imenom Metodika pouka geografije prvič postala visokošolski predmet. Znanstvenoraziskovalna in pedagoška dejavnost, ki se je sprva razmahnila z ustanovitvijo Inšituta za geografijo Univerze, se je kasneje razširila tudi z že obstoječima geografskima inštitucijama ter z ustanovljenima geografskima oddelkoma v okviru ljubljanske in mariborske Pedagoške akademije.

To je bil čas, ko se je začela slovenska pokrajina pod vplivom policentrično zasnovane industrializacije, $\mathrm{z}$ njo povezane urbanizacije in deagrarizacije, ter odpiranja državnih meja hitro spreminjati, podeželje pa tudi regionalno diferencirati. Študijam, ki so obravnavale pojave $\mathrm{z}$ izhodišč posameznih geografskih vej (agrarne, industrijske, prebivalstvene, turistične, prometne) so se pridružile študije, ki so posvečale pozornost problemom posamezne regije ali celotne Slovenije. V tem času se je tudi geografija počasi izvijala iz tradicionalističnih okvirov. V ospredje so vse bolj prihajali interdisciplinarnost in problemi pokrajine v industrijski družbi z vplivi mednarodnega tranzitnega položaja, odprtosti proti razvitemu evropskemu svetu in prostorske funkcije Slovenije kot obmejne regije Jugoslavije. Zaradi negativnih ekoloških učinkov industrializacije in urbanizacije je bilo več pozornosti posvečene ekološkim problemom in varovanju naravnega okolja. Rezultati tega dela so v novejšem času na eni strani študije po posameznih vejah geografije (turizem, industrija, prebivalstvo, hidrogeografija, ekologija itd.), na drugi strani pa študije o podeželju, obmejnih regijah in drugih tipih pokrajin. Zadnja desetletja so bili izdani številni visokošolski učbeniki (o regionalnem planiranju, pokrajinski ekologiji, matematični geografiji, agrarni geografiji, politični geografiji itd.) in zborniki z geografskih posvetovanj.

Raznolikost konceptov, ki jo je zaznati v delu univerzitetnih sodelavcev, je plod njihovega povezovanja s številnimi geografskimi šolami po Evropi, pa tudi zunaj nje. S hitrim razvojem geografije je povezano povečanje števila učiteljev in sodelavcev ter tudi vedno večje število slušateljev geografije. $V$ devetdesetletnem razdobju se je od enega učitelja $\mathrm{z}$ asistentom razvila sodobna pedagoška in znanstvena geografska ustanova. Zaradi potreb po poglobljenem znanju geografov na negeografskih področjih, so bili več kot dve desetletji s svojimi predmeti in širokim znanjem vključeni v pedagoški proces Anton Ramovš z geologijo, Zdravko Petkovšek z meteorologijo ter Miran Čuk s statistiko. Pri snovanju katedre za didaktiko geografije sta sodelovala Dušan Kompare in Mavricij Zgonik. Delo teh prvih sodelavcev so nadaljevali njihovi nasledniki iz negeografskih in geografskih vrst.

Povečanje števila učiteljev in asistentov je omogočilo temeljito preoblikovanje študijskega programa. Poleg dvostopenjskosti in dvopredmetnosti študija je bilo prav gotovo najpomembnejše približevanje programa potrebam prakse in to ob poudarjeni skrbi za sledenjem razvoja metodologije in teorije stroke. Poleg pedagoške je bila oblikovana tudi nepedagoška smer študija geografije, ki je v 90-tih letih prejšnjega stoletja iz dvopredmetne prerasla v samostojno smer. Znotraj te smeri se je izoblikovalo pet področij (usmeritev), ki jim oddelek - kot odziv na potrebe prakse - namenja posebno pozornost: geografija krasa, geografija turizma, politična geografija, varstvo geografskega okolja in prostorsko planiranje. 
Konec 90-tih let prejšnjega stoletja je prenovljeni oziroma poenostavljeni študijski program polno zaživel. Opuščena je bila dvopredmetna nepedagoška smer, obenem pa sta se izenačila A in B predmet, tako da je postal študij geografije dvosmeren: na eni strani je bila samostojna nepedagoška smer, na drugi pa dvopredmetna pedagoška smer. Predvsem pri nepedagoškem študiju je potrebno omeniti tradicionalno študijsko povezovanje z drugimi strokami, tako naravoslovnimi kot družboslovnimi in humanističnimi, kar se bo še okrepilo s prehodom na bolonjski študij.

Da je študij geografije dobil pri študentih primeren odziv, dokazuje tudi močna obštudijska dejavnost študentov. Organizirani v Društvo mladih geografov Slovenije prirejajo raziskovalne tabore, se udeležujejo študentskih strokovnih srečanj v tujini in gostijo tuje študente pri nas. Izdajajo lastno glasilo Geomix, v katerem prevladujejo strokovne vsebine in prispevki o študiju.

Postopoma se je izoblikovala osrednja geografska knjižnica z blizu 100.000 knjižnimi enotami, bogata kartografska zbirka, obenem pa se je posodabljal tudi fizičnogeografski laboratorij.

Ob praznovanju devetdesetletnice ljubljanske univerze lahko ugotavljamo, da se je geografska znanost na področju metodologije, teorije in aplikacije vsebinsko razvijala in spremljala razvoj geografske znanosti v svetu. Učitelji in sodelavci Oddelka za geografijo so bili tudi vodilni sodelavci Geografskega inštituta pri Slovenski akademiji znanosti in umetnosti in Inštituta za geografijo Univerze, tako pri vodenju raziskovalnega dela kot pri urejanju revij. S kadrovsko krepitvijo geografskih inštitutov se je zmanjševalo sodelovanje z Oddelkom za geografijo, posebno na raziskovalnem področju. Za opravljanje raziskovalnega dela se je moral oddelek vključiti v Znanstveni inštitut FF, a pri tem je ostal skoraj brez kadrovske in opremske infrastrukture, nujno potrebne za raziskovalno delo. Nov način financiranja raziskovalnega dela prek programov (srednjeročno, usmerjeno financiranje) in prek projektov (tržno, delno usmerjeno financiranje) je zahtevalo ovrednotenje dotedanjega raziskovalnega dela in oblikovanje novih raziskovalnih skupin. Podobno se je zgodilo s strokovnimi publikacijami: vedno manjše možnosti objavljanja znanstvenih in strokovnih prispevkov v glasilih geografskih institucij je prisililo oddelek, da je leta 1985 začel izdajati lastno znanstveno revijo DELA, ki od takrat kontinuirano izhaja, ves čas pa je oddelek izdajal tudi priložnostne publikacije. Leta 2009 je izšel tudi prvi GeograFF, ki je nova oddelčna serija znanstvenih monografij.

Sodelavci Oddelka za geografijo ves čas od nastanka Geografskega inštituta po prvi svetovni vojni posvečajo vso pozornost razvoju teorije, metodologije in aplikacije. V vsej svoji zgodovini se oddelek nikoli ni zapiral sam vase, ampak je ustanavljal ali pomagal ustanavljati različne geografske ustanove, tako pedagoške kot raziskovalne. Učitelji Oddelka za geografijo so tako v preteklosti kot danes predavali tudi zunaj Filozofske fakultete (npr. na interdisciplinarnem podiplomskem študiju regionalnega planiranja na takratni Fakulteti za arhitekturo, gradbeništvo in geodezijo, na Pedagoški fakulteti v Mariboru, na Biotehniški fakulteti v Ljubljani, na Turistici - Visoki šoli za turizem v Portorožu in na Fakulteti za humanistične študije v Kopru, na Prirodoslovno-matematičnih fakultetah v Sarajevu in Tuzli, na Univerzi v Celovcu itd.). Rezultate svojega raziskovalnega dela sodelavci oddelka sproti 
objavljajo v slovenskem in tujem geografskem tisku. Z vse bolj organiziranim raziskovalnim delom v svetu povezujejo svoje delo v komisijah in delovnih skupinah Mednarodne geografske unije, kjer so bili oziroma so še vodje, člani vodstev ali pa člani komisij in delovnih skupin. Aktivno sodelujejo na številnih domačih in mednarodnih geografskih in drugih posvetovanjih, seminarjih, konferencah itd., obenem pa so tudi sami organizirali več zelo odmevnih prireditev. Na oddelku gostujejo strokovnjaki iz različnih evropskih in neevropskih držav, kar predstavlja velik, predvsem pa kvaliteten doprinos k študiju in delu na oddelku, ravno tako pa naši učitelji zelo pogosto predavajo na tujih univerzah širom po Evropi ter v ZDA, na Novi Zelandiji in v Avstraliji. Posledica povezovanja s tujimi univerzami je tudi bogata izmenjava študentskih ekskurzij. Na Oddelek za geografijo redno prihajajo mladi raziskovalci na raziskovalno izpopolnjevanje iz evropskih pa tudi neevropskih dežel. Člani oddelka so za svoje predano znanstvenoraziskovalno in pedagoško delo prejeli številna domača in tuja priznanja ter nagrade.

Z namenom dvigniti kvaliteto študija in motivirati študente za delo, so bila leta 2000 uvedena Priznanja Oddelka za geografijo FF UL. Podeljujejo se za nadpovprečno kakovostne pisne izdelke (seminarske naloge, diplomska dela) študentov. Prešernova nagrada, ki jo dobi praviloma le eden z Oddelka, za tako množične populacije ne zadošča več, škoda pa bi bila, da bi bila kakovostna dela prezrta.

V letu 2005 je Oddelek začel s pripravo prenove študijskih programov po bolonjskih smernicah. Akreditirani so trije študijski programi in sicer Prvostopenjski univerzitetni študijski program Geografija - enopredmetni, Prvostopenjski univerzitetni dvodisciplinarni študijski program Geografija ter Drugostopenjski magistrski program Geografija, medtem ko je v postopku akreditacije Drugostopenjski univerzitetni dvopredmetni pedagoški program Geografija. Doktorski študij je organiziran v okviru interdisciplinarnega doktorskega študija humanistike in družboslovja, ki ga vodita Filozofska fakulteta in Fakulteta za družbene vede Univerze v Ljubljani.

Danes je na Oddelku za geografijo zaposlenih 12 učiteljev, 8 asistentov, 2 strokovni sodelavki, 1 tajnica oddelka, 4 knjižničarke, 1 laborantka, 2 sodelavki v Raziskovalnem centru, v pedagoškem procesu pa sodelujejo še 4 zunanji učitelji in 1 lektorica.

\section{PRAZNOVANJE 90-LETNICE ODDELKA ZA GEOGRAFIJO FILOZOFSKE FAKULTETE UNIVERZE V LJUBLJANI}

$\mathrm{Na}$ Oddelku za geografijo je bilo posebno praznično 6. novembra 2009. V dopoldanskih urah je bil v prostorih Oddelka znanstveni sestanek z naslovom »Sodobni izzivi povezovanja med univerzitetnim študijem in znanstvenim raziskovanjem v geografiji

Po uvodnem pozdravu predstojnice Oddelka dr. Tatjane Resnik Planinc je svoje poglede na vlogo geografije v 21. st. predstavil dr. Dušan Plut. Poudaril je ključne raziskovalne izzive, s katerimi se bo srečala geografija v novem stoletju: usmerjena specializacija, projektno vodeno skupinsko delo, potreba po geografski prognozi, preučevanje trajnostnega regionalnega razvoja ter naraščajoči geopolitični, gospodarski, družbeni in okoljski izzivi sodobne družbe. 


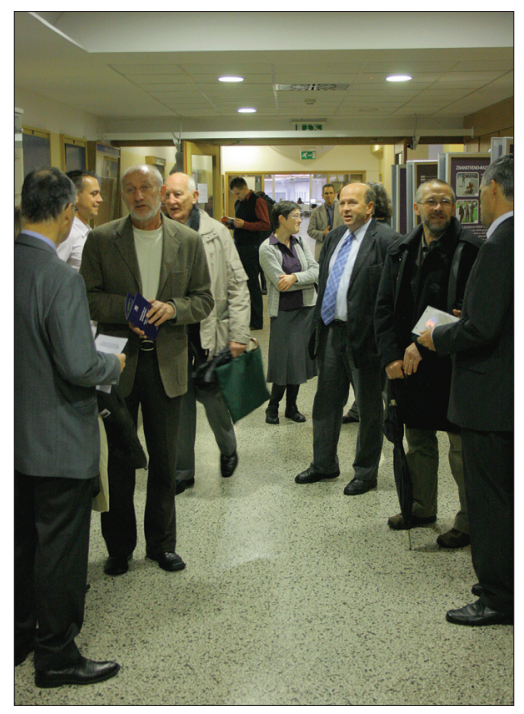

Slika 2: Zbiranje udeležencev znanstvenega sestanka na hodniku Oddelka za geografijo FF UL (foto: B. Repe)

Sledila so predavanja predstavnikov posameznih kateder in vsebinskih usmeritev ljubljanske geografije, ki so, podobno kot prvi govornik, poskušali opredeliti prihodnji razvoj posameznih vej geografije. Vsi so se strinjali, da je naloga geografije preučevanje pokrajinske pestrosti in kompleksnosti. S svojimi pogledi lahko pomembno prispeva $\mathrm{k}$ uspešnemu reševanju razvojnih težav $\mathrm{v}$ Sloveniji in $\mathrm{v}$ njenih regijah. Na znanstvenemu sestanku so s svojimi referati sodelovali tudi predstavniki geografskih izobraževalnih organizacij iz Slovenije in drugih držav (Avstrija, Hrvaška, Velika Britanija).

Slika 3: Znanstveni sestanek Oddelka za geografijo FF UL (foto: B. Repe)

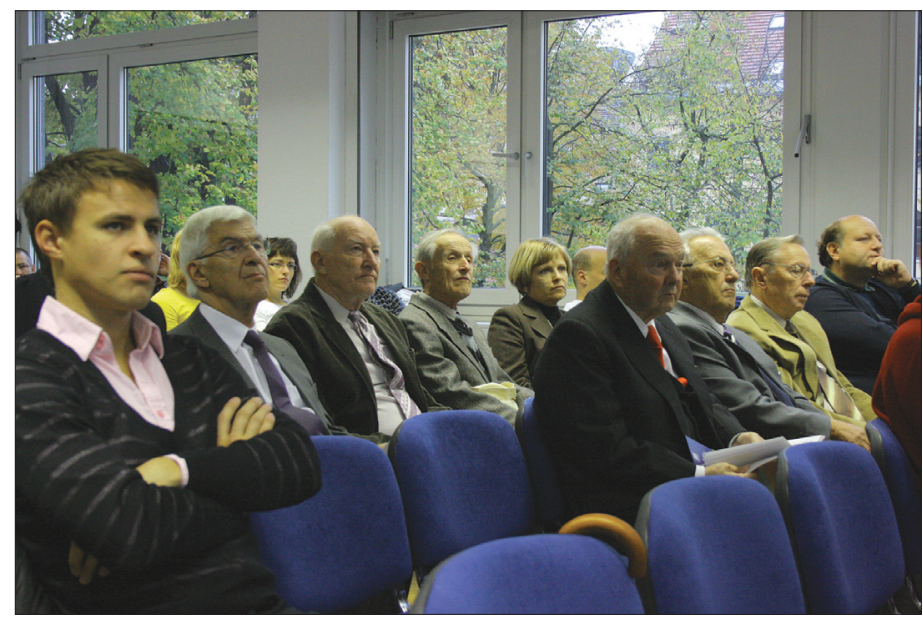

V poznih popoldanskih urah je potekala v hotelu Lev svečana akademija. Po uvodnem pozdravu predstojnice Oddelka za geografijo dr. Tatjane Resnik Planinc so prisotne pozdravili dekan Filozofske fakultete dr. Valentin Bucik ter predstavniki drugih geografskih organizacij iz Slovenije in tujine: dr. Matija Zorn (Geografski inštitut Antona Melika ZRC SAZU), dr. Uroš Horvat (Oddelek za geografijo Filozofske fakultete Univerze v Mariboru), dr. Anton Gosar (Oddelek za geografijo kontaktnih prostorov Fakultete za humanistične študije Univerze na Primorskem), dr. Tadej Slabe (Inštitut za raziskovanje krasa ZRC SAZU), dr. Matej Gabrovec (predsednik Zveze geografov Slovenije), Nina Peca (predsednica Društva 
Mladih geografov Slovenije) in dr. Ivo Nejašmić (Oddelek za geografijo Prirodoslovnomatematične fakultete Univerze v Zagrebu).

Slika 4: Svečana akademija Oddelka za geografijo FF UL (foto: M Rebolj)

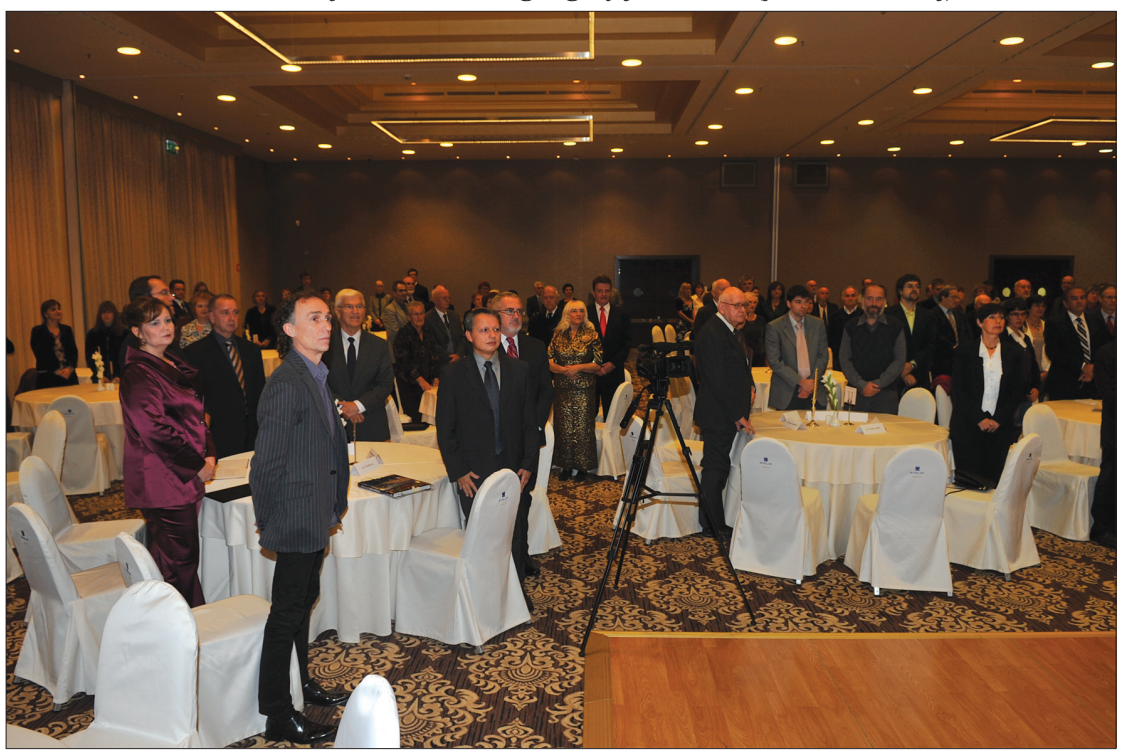

Slika 5: Govor dekana Filozofske fakultete UL dr. Valentina Bucika na svečani akademiji (foto: B. Repe)

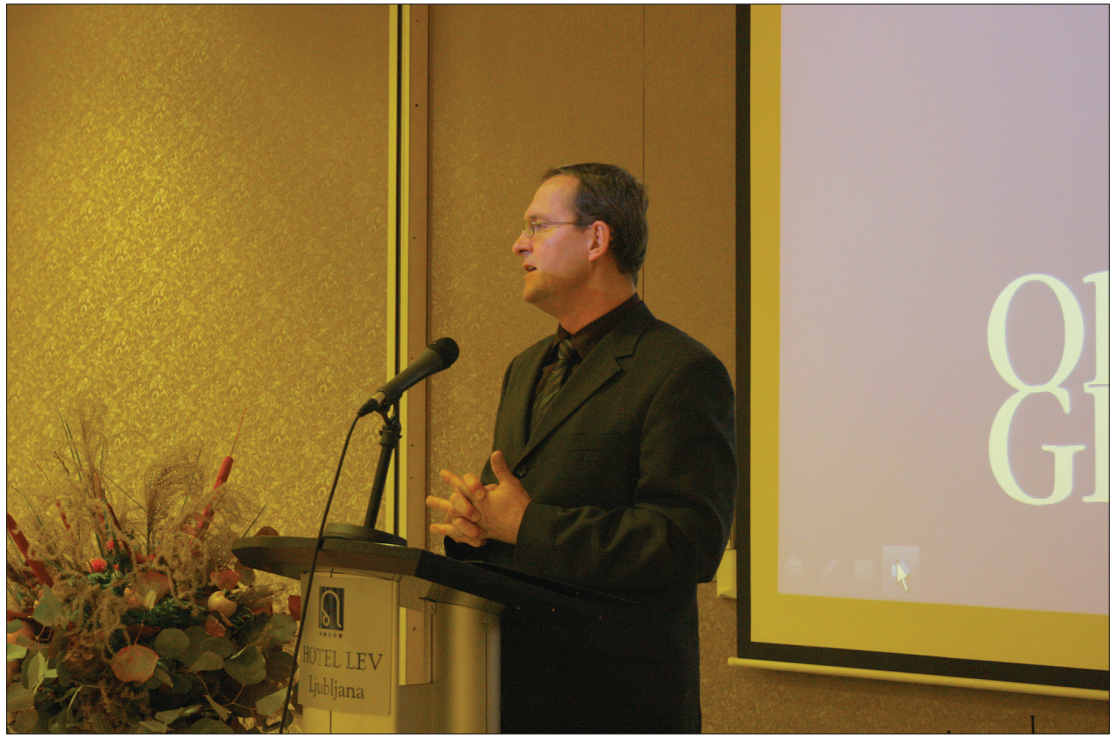


Sledili sta predavanji slavnostnih govornikov. Dr. Marijan Mihael Klemenčič (Oddelek za geografijo FF UL) je v svojem govoru poudaril prednosti geografije, hkrati pa izpostavil nekatere izzive, ki vplivajo na stopnjo strokovne samozavesti. Sledilo je predavanje dr. Hartwiga Haubricha (upokojeni profesor Visoke pedagoške šole v Freiburgu) o trajnostnem razvoju kot izzivu za Evropo in ves svet.

$\mathrm{Na}$ svečani akademiji so bila podeljena priznanja upokojenim sodelavcem Oddelka za geografijo, zunanjim sodelavcem, uglednim znanstvenikom in profesorjem geografije iz tujine, ki so posebno močno povezani z Oddelkom za geografijo, ter dvema društvoma. Priznanja so prejeli: Tončka Abbad, dr. Franc Lovrenčak, dr. Mirko Pak, akademik dr. Andrej Kranjc, dr. France Šušteršič, dr. Andrej Pogačnik, dr. Jörg Maier, dr. Hartwig Haubrich, dr. Antonin Vaishar, dr. Karl Donert ter Društvo učiteljev geografije Slovenije in Društvo mladih geografov Slovenije.

Slovesno akademijo so popestrili pevski zbor študentov geografije, sedanji in nekdanji študenti geografije ter voditeljica Blažka Müller Pograjc.

Slika 6: Pevski zbor študentov geografije Oddelka za geografijo FF UL (foto: B. Repe)

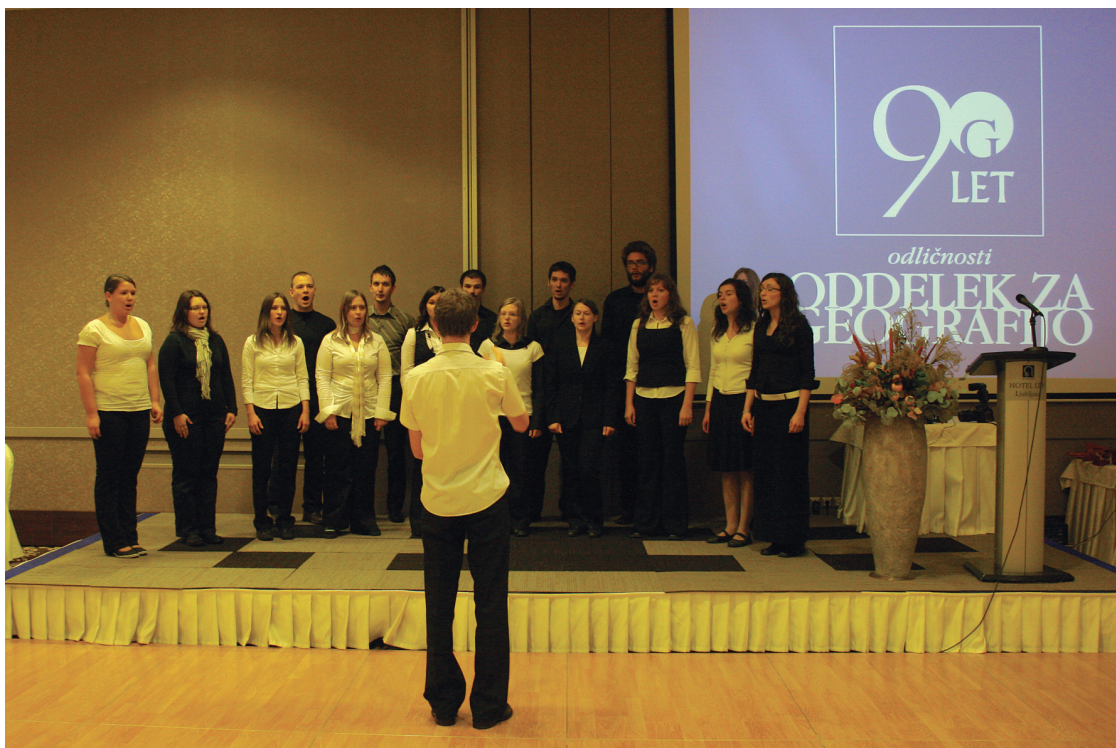

S tem dogodkom se praznovanje visokega jubileja ljubljanskega Oddelka za geografijo še ni končalo. Alumni klub geografov Univerze v Ljubljani, ki združuje diplomante ljubljanskega Oddelka za geografijo, je v hotelu Lev organiziral večerno »Srečanje generacij«. Z njim je Alumni klub obeležil tudi svojo 10-letnico. Po uvodnem pozdravu njegovega predsednika dr. Mitja Briclja je sledila slovesna večerja. Po njej je za plesno glasbo skrbel ansambel Melanholiki. Sproščeno druženje s klepetom, plesom, hrano in pijačo ter bogatim srečelovom se je nadaljevalo v zgodnje jutranje ure. 
Slika 7: Srečanje generacij (foto: M. Rebolj)

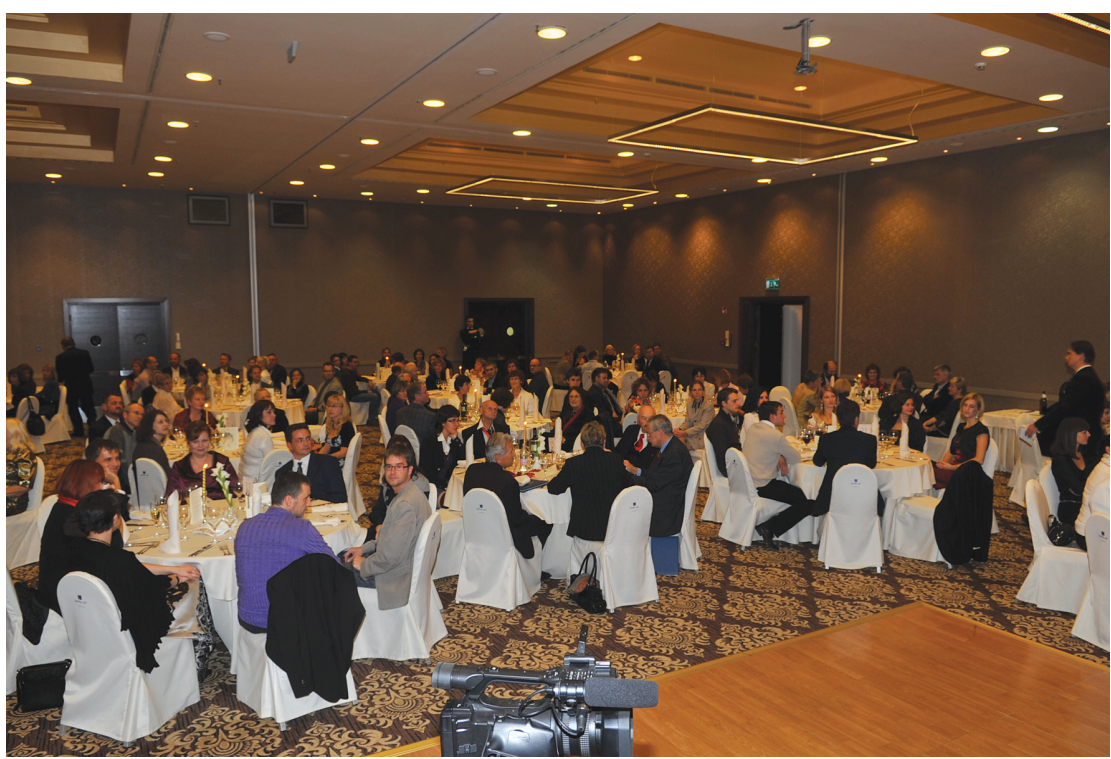

V okviru praznovanja 90-letnice Oddelka za geografijo FF UL so bili izdani zloženka s predstavitvijo knjižnice Oddelka, brošura s predstavitvijo Oddelka in študijskih programov v slovenskem in angleškem jeziku, izšla pa je tudi 32. številka znanstvene revije DELA, ki jo izdaja Oddelek za geografijo FF UL. V njej so predstavljeni pogledi na pretekli razvoj geografije v Sloveniji in na ljubljanskem Oddelku za geografijo, nakazani pa so tudi potenciali za prihodnji razvoj vede.

Vseh treh prireditev, ki so bile pripravljene ob praznovanju 90 let Oddelka za geografijo FF UL, se je udeležilo veliko število geografov, ki so s tem dokazali, da še vedno čutijo z geografijo in z organizacijo, ki jih je popeljala v svet geografskega pogleda na pokrajino.

Tatjana Resnik Planinc, Simon Kušar 